\title{
"Mildly Theatrical": Attending (to) The Awkward Age
}

PHILIP HORNE University College, London

The act of attention — of listening, of watching, of sensing, of thinking-is central to James's art and his notion of experience. "Try to be one of those on whom nothing is lost." But in the special case of The Awkward Age, a special kind of attention is especially demanded-one which particularly involves listening.

At the start of an Ibsen play, James says in his Preface to The Awkward Age, the

spectator or reader... is to be caught at the worst in the act of attention, of the very greatest attention, and that is all, as a precious preliminary at least, that the playwright asks of him, besides being all the very divinest poet can get. I remember rejoicing as much to remark this, after getting launched in The Awkward Age, as if I were in fact constructing a play... (FW1133)

So The Awkward Age sets off, as it were, flying the pennant of Ibsen-and of the drama. This is, however, also one of the main reasons why despite having its passionate adherents, The Awkward Age presents difficulties peculiar and unique among James's works - which even when they are as demanding as The Ambassadors, The Wings of the Dove or The Golden Bowl tend to cleave closely to a 
character's consciousness-so that we can get through them, as James does in The American Preface, by "clinging to [the] hero as to a tall, protective, good-natured elder brother in a rough place" ( $F W 1069)$. Here the reader is a spectator, as it were in front of the action, facing the stage- hence what the Preface calls

the imposed absence of that "going behind," to compass explanations and amplifications, to drag out odds and ends from the "mere" storyteller's great property-shop of aids to illusion ( $F W 1131)$

The "odds and ends" include any significant reference to the past in flashbacks or in "harking back to make up," as James calls them in the Preface to The Ambassadors, and also elisions within chapters ( $F W 1317)$. The present action flows continuously and depthlessly before us, all on "one plane of exhibition," as James says in the Awkward Age Preface (FW 1134). ${ }^{1}$ Disembodied, away from the peopled theatre, it can be hard to read.

The publishing of plays—rare in the English-speaking world till 1891 and the changes brought about by the International Copyright Treatywas something that James had views about, expressed in the quasi-dramatic critical discussion "After the Play" (1889) where the most James-like of the interlocutors, Dorriforth, complains of "our contemporary drama"

To begin with, you can't find it — there's no text [...] One can't put one's hand upon it; one doesn't know what one is discussing. There is no "authority" — nothing is ever published. (CWD 356)

There was a text five years later, at least, in James's two Series of Theatricals, both published in 1894 (June and December), but the four plays published there were only published; they had fallen foul of the conditions of the British theatre-had gone unproduced—and "my good Comptons," the Compton Comedy Company, for whom they'd been written, had dictated the

1 I am grateful to Jean Gooder, Adrian Poole and Christopher Ricks, kind and acute readers, for their help and encouragement both with this essay and more generally for many years past. I owe thanks also to the members of my Henry James Reading Group at UCL, without whose communal and collaborative reading of The Awkward Age in the autumn of 2018 this line of thought could not have emerged. James writes of 'the beauty and the difficulty (to harp again on that string) of escaping poverty even though the references in one's action can only be, with intensity, to each other, to things exactly on the same plane of exhibition with themselves' ( $F W 1134)$. 
unambitious limits within which James had to stick ( $L L$ 237; 8 January 1891). In his fascinating "Note" to Theatricals, Second Series, James takes consolation from this printed performance, as one might call it:

Of a published play... it cannot exactly be said that it has not been performed at all; for the disconcerted author at least-if, as he has wrought, the thing has arrived at adequate vividness - the printed book itself grows mildly theatrical, the frustrated effort approximately positive. (CP 347)

"The printed book itself grows mildly theatrical": the reader becomes a spectator and auditor, supplying in imagination the stage and footlights, the production, the cast, the interpretation. At least it's beyond the thousand natural shocks of actual West End realisation - shocks which, as is widely known, would put an end to James's sustained period of engagement with the theatre. On 10 January of the following year, 1895, he was writing to Henrietta Reubell:

I felt with bottomless dismay how the atmosphere of any London theatre is in mortal danger of becoming a complete non-conductor of any fine intention or any really civilized artistic attempt. (LL 275)

The vocal hostility of part of the audience at the première of Guy Domville, on which he comments here, only confirmed James's sense of the forces arrayed against satisfying theatre in Britain.

This essay examines some connections between the unfinished business of Guy Domville and Theatricals and the mode of The Awkward Age, which aspires, famously, to work through "really constructive dialogue, dialogue organic and dramatic, speaking for itself, representing and embodying substance and form," which James says is "among us an uncanny and abhorrent thing, not to be dealt with on any terms" (FW 1127). And Ibsen, bulking so unexpectedly large in The Awkward Age Preface, plays a part here. For, as Michael Egan remarks in Henry James: The Ibsen Years, "James's encounter with Ibsen made novels like What Maisie Knew (1897) and The Awkward Age (1899) possible" (Egan 312). In 1897 James had remarked, à propos of Ibsen's John Gabriel Borkman: "That no one ever does read a play has long been a commonplace of the wisdom of booksellers. Ibsen, however, is a text, and Ibsen is read, and Ibsen contradicts the custom and confounds the prejudice" (CWD 454). And reading John Gabriel Borkman, James comments that "the whole thing throbs with an actability that fairly shakes us as we read" (455; my italics). "Actability" 
is an alluring term too with regard to The Awkward Age, where, as we've seen, "The printed book itself grows mildly theatrical."

Theatrical production gives a text a physical reality: bodily presences, a defined space, a duration shared between actors and audience, a set of individuals' voices and what Wagner calls a "sound-world" (qtd. in Halliday 33)—and also makes interpretative choices, beyond the text-gestures, intonations, postures, blocking, costumes, sets, make-up, musical accompaniment, often more. That is the theatre's vividness. Such triumphs, however inspiring, though, however valuable, are short-lived-and anyway are fluctuating, indefinable. Theatre history deals in records, however striking, of evanescent performances. But not only are there numerous, differing performances, any one performance is anyhow in itself a personal matter for audiences. One spectator is moved, another bored; one dozes in the front stalls, another is rapt in the "gods" despite a restricted view. So a performance-like any event-is not a simple or single thing in the first place, even before it decays and memories of it become distorted. We can sharpen and refine our responses, but could never find, and therefore should not pointlessly seek, a fixed meaning.

Intensely moving or delightful at the time, though, like Coquelin's acting in Charles Lomon's Jean Dacier in September 1877 which so thrilled James he walked the Parisian streets well into the night, were the achievements of actors in the French tradition-actors for whom James could never hope to write- and they could serve as an inspiration to him in his own field. As he had registered explicitly in 1887, writing about writing about his former Boulogne schoolmate Charles Coquelin's Duc de Septmonts in L'Étrangère by Dumas fils:

There is something in the way M. Coquelin goes through this long and elaborate part, all of fine shades and minute effects, all [appealing] to the finest observation as well as displaying it, which reminds one of the manner in which the writer of a "psychological" novel (when he knows how to write as well as M. Coquelin knows how to act) builds up a character, in his supposedly uncanny process-with touch added to touch, line to line, and a vision of his personage breathing before him. M. Coquelin is really the Balzac of actors. $(C W D 333)^{2}$

2 Peter Collister in his edition of James's writings on Drama usefully gives in an Appendix 
Putting this together with the vivid impression, indeed the "throb" and the "shake," caused in James by his reading of Ibsen in 1897, one can see the appeal for him of a formal experiment that would take the lessons of the theatre and exhibit them in the controllable arena and under the favouring light of blackand-white, durable prose fiction-especially since by now the three-decker Victorian-style had collapsed-collapsed in 1894, as it happened, when the circulating libraries ceased to prop it up. ${ }^{3}$ The dimension of the novel as a constructed performance may also have come home to James in February 1897 during the composition of What Maisie Knew with the failure of his wrist and his new habit of dictation, which allowed and required a constant voicing of his prose (by him) and a responsive re-sounding of it on the Remington by his first amanuensis William McAlpine.

The rules James sets himself in The Awkward Age are extraordinary: challenging for him and for us, and controversial-it's a novel many people can't get on with-for want, as I've said, of an authorially known consciousness to cling to as a guide for us through the novel's great stretches of talk (as well as the want of a strong and unmistakeable dramatic situation). The mode James chooses is that of putative or hypothetical performance-performability,

James's much-revised 1915 version of the essay, where this passage reads: 'M. Coquelin's progress thru [sic] this long and elaborate part, all of fine shades and pointed particulars, all resting on the keenest observation as well as appealing to it, resembles the method of the "psychological" novelist who (when he is in as complete possession of his form as M. Coquelin of his) builds up a character, in his supposedly uncanny process, by touch added to touch, line to line, illustration to illustration, and with a vision of his personage breathing steadily before him. It wouldn't take much more than my remembrance of the Duc de Septmonts at the Français to make me pronounce his exponent really the Balzac of actors' ( $C W D$ 545).

3 Peter Keating's account of the event is vivid: “On 27 June 1894 Mudie's and Smith's announced that from the beginning of the following year they would pay no more than 4/(less the usual discounts) per volume for fiction, and that the publishers must agree not to issue cheap editions of books purchased by the libraries until one year after publication. It was an ultimatum. ... The two main aims of the ultimatum were to render the publication of three-volume novels uneconomic, and to encourage publishers to issue new fiction in single-volume form. Both aims were quickly successful. The number of three-volume novels published in 1894 was 184; this fell to 52 in 1895, 25 in 1896, and 4 in 1897" (Keating 25-26). 
"actability" - the "might have been" of the hypothetical theatrical situation: If someone had been watching or listening, as at a play, this is how they might have interpreted the action. ${ }^{4}$

An example. Near the end, Nanda heroically tries to defend Van's conduct to Longdon-pained, he stops her, and she may have to acknowledge that even she isn't capable of such nobility and self-denial. Longdon says, "Don't!", and

She had kept, for the time, all her fine clearness turned to him; but she might on this have been taken as giving him up with a movement of obedience and a strange soft sigh. The smothered sound might even have represented to a listener at all initiated a consenting retreat before an effort greater than her reckoning - a retreat that was in so far the snap of a sharp tension. ( $A A 450)$

There's one immediate, representative difficulty here: are the two "hims" in the first sentence the same person? The first seems like Longdon, who's there ("all her fine clearness turned to him"); the second ("giving him up") like Van ... since she's obeying Longdon. Why not say so, why not disambiguate? James seems to want us so finely attuned we need no nudge to see this distinction. The "strange soft sigh" alliteratively matches the "smothered sound" and thenweirdly, paradoxically—represents the "snap of a sharp tension." What such a translation of "soft sigh" to "snap of a sharp tension" depends on is someone who "might... have been" present, might have seen and heard, might have interpreted; and-James pushes harder for the larger significance - under such putative scrutiny A "might even have represented" B-that is, rather bracingly perhaps, "to a listener at all initiated" (my italics). This imagined audience is a constantly invoked, constantly implied element in The Awkward Agethe "continuous spectator of these episodes" ( $A A$ 432) who notes gestures, insistences, silences, resemblances-and must undergo an initiation in order to cope with such difficulties.

Jean Gooder, in a suggestive essay on The Awkward Age from 1984, "The Awkward Age: A Study in Ephemera?", notes that the lack of guiding narration leaves us "no interpretive guide but our own ear for intonation" (Gooder 25.)

4 As Adrian Poole notes, here "those tenses - and moods ((subjunctive, optative) — are crucial"; the drama takes place in the present tense, before our eyes-but it's also implicitly a narrated, shaped re-presentation of events already past and not to be changed (though perhaps to be made available for re-interpretation) (personal communication, January 2020). 
And our "ear"-for intonation — may be fallible, may miss the connection between "snaps" and "sighs". James has a fine phrase for it in the revised text of the Coquelin essay - "The ear of the public, that field of the auditive intelligence" $(C W D 539)^{5}$ - only then to remark that, in the theatrical culture of the time, this "ear" has "simply ceased to respond for lack of use." This unresponsiveness and desuetude was problematic for James, and may be for us, in The Awkward Age, where tone is in so many ways the heart of the subject: that of Nanda's entry-coming "downstairs"-into a social circle of soi-disant fine intelligences—a circle defined, as the "Preface" says, by "a tone as far as possible removed from that of the nursery and the schoolroom" ( $F W 1123$ ). In fact, as Jean Gooder says, "The Awkward Age creates its own reality, as we become aware of tone, differences and samenesses between the characters, and learn to follow references which are made, and dropped, to re-appear with fresh point" (29).

The novel has to educate us then, as we read, in how to read it-and though James would never be so crudely avant-gardist as to issue a "manifesto," here as elsewhere he drops some fairly arresting hints. When Longdon is with Nanda towards the end of the novel, we are told that "He looked at her with a complexity of communication that no words could have meddled with" ( $A A$ 450). This spells out the power of the look, and the dramatic possibilities of silence-recalling the great moments of the stage and, we might say, anticipating one of the great gifts of the cinema. The words cannot "meddle" both in the sense that Longdon can't find words, and that James's narration can't or won't find them. This is the ineffable, with which by definition you must not eff-eff being here, etymologically, from the Latin effari, to speak out. ${ }^{6}$

At times James, released from the clumsiness of British theatrical production, imagines moments of almost impossibly refined communicationdemanding of his imaginary performers supreme feats of nuance and exactness in registration, wanting from his Mitchy, as it were, what he noted in Coquelin:

\footnotetext{
5 This is 1915; in 1887 it was 'that exquisite critical sense' and 'from want of use' (CWD 329).

6 Wittgenstein in 1922 put it another way: 'Whereof one cannot speak, thereof one must be silent' (189)
} 
a range and a use of tone, a directed application of it, which are peculiar to the artist who commands them and are surely the most wondrous in their kind that the stage has ever known (CWD 537 [1915] $)^{7}$

In fact the thought occurs that Mitchy-whose portrayal throughout the novel, "the presentation, throughout, of a Mitchy 'subtle' no less than concrete," is singled out by James in the Preface as one of its greatest achievements ( FW 1136) — is exactly a part for Coquelin, most famous as Cyrano de Bergerac in Rostand's 1897 play of that title, which was highly praised by James in his essay on Rostand (there is on YouTube, indeed, a piece of experimental sound film of Coquelin in the part from 1900). ${ }^{8}$

Here then, for example, are Van and Mitchy, in Longdon's library at night, discussing everyone's "tact” towards Van:

"Oh, it's all right," Vanderbank immediately said. "Your 'tact'-yours and his—is marvellous, and Nanda's greatest of all."

Mitchy's momentary renewal of stillness was addressed, he managed, somehow, not obscurely to convey, to the last clause of his friend's speech. (AA 314)

Such articulations of response and "complexity of communication" seem to challenge an ideal actor to summon a tremendous clarity of point, through "stillness" - a pause addressed just "to the last clause" - and to do so without strain: "he managed, somehow, not obscurely to convey..."

James's "auditive intelligence" in The Awkward Age is perhaps most rewardingly shown in particular scenes; for scenes are, as James says in A Small Boy and Others (1913), "the root of the matter" ( $A$ 159). One scene James picks out in the Preface among "the positively most artful passages" in The Awkward Age is Chapter XX, "the hour of Mr Longdon's beautiful and, as it were, mystic attempt at a compact with Vanderbank, late at night, in the billiard-room of the country-house at which they are staying" ( $F W 1136)$. James deliberately frames

7 In 1887 "a range and a use of tone, a directed application of it" was simply "a faculty of vocalization, as one may call it" (CWD 326).

8 See https://www.youtube.com/watch?v=-tzmls4gTgQ 
the billiard-room at Mitchy's rented house as a silent, resonant space in which the two men can sound and test each other. Early in the chapter, Longdon

spoke with a weight that, in the great space, where it resounded a little, made an impression - an impression marked by the momentary pause that fell between them. He partly broke the silence, first, by beginning to walk again, and then Vanderbank broke it as through the apprehension of their becoming perhaps too solemn. (AA 216)

Longdon's emphasis seems too loud in this acoustic, evokes an echo that silences both men: a silence they both feel must be broken-partly by one, then completely by the two together-before it becomes oppressive. In the resonant space this sets up, James can register tiny nuances and sound effects.

James is fond of the partly new-technological word "click," which he applies to electric light switches, typewriters, horses' hooves, footfalls-and mental processes. ${ }^{9}$ In "Richard III and Little Eyolf" (1897), he applies it to the thrill of absorption - of what he calls in the Awkward Age Preface "the act of attention, of the very greatest attention"-that befalls the serious Ibsenwatcher at a certain point:

within five or ten minutes of the rise of the curtain — a moment at which this special spectator becomes aware of an adjustment of his aesthetic sense as definite as a material "click." It is simply the acceptance of the small Ibsen spell, the surrender of the imagination to his microcosm, his confined but completely constituted world, in which, in every case, the tissue of relations between the parts and the whole is of a closeness so fascinating. (CWD 451)

The spectator, we might say, is "turned on" - a phrase James himself uses (it was well-established for water, steam, gas and electric current). "Click" also occurs to break the silence of the billiard-room scene in The Awkward Age, where Longdon and Van guardedly manoeuvre as they talk and Longdon makes his offer, his "bribe." "Here we are," says Van at one point-of their confrontation, but also of this metaphorically loaded room of strokes, angles, tight corners.

9 Melanie Ross in her paper on "Speech-into-Writing" at the 2019 Trieste conference drew attention to the way that for James in his notebooks a 'click' was often the image for a shift or advance in James's own thinking: where he's just declared 'eureka,' he calls it 'a little click of perception' (N217). 
His companion looked at him a moment longer, then, turning away, went slowly round the table. On the further side of it he stopped again and, after a minute, with a nervous movement, set a ball or two in motion. "It's beautiful-but it's terrible!" he finally murmured. He had not his eyes on Vanderbank, who for a minute said nothing, and he presently went on: "To see it and not to want to try to help-well, I can't do that." Vanderbank still neither spoke nor moved, remained as if he might interrupt something of high importance to him, and his friend, passing along the opposite edge of the table, continued to produce in the stillness, without the cue, the small click of the ivory. "How long-if you don't mind my asking-have you known it?" (AA 219-20)

One notes in this the intricacy of the way setting balls in motion rhymes with the strokes of conversation-making statements or asking questions or even staying silent; and the delineated stages: the delay in the look, then the turn, then the slow circuit, the minute's delay-before the "final" murmur. Van in turn delays a minute-so Longdon speaks again-but only "presently." Van still keeps silent-but respectful and attentive-and Longdon goes on setting balls in motion. "Without the cue" literally and primarily means without the cue-stick-but also puns on a theatrical "cue," means (perhaps) that like an actor whose colleague "dries" onstage, he goes on without the prompt of a response. And of course what most resonates for this argument is "the small click of the ivory," alerting us to the acoustics of the room. The click seems to prompt his next question-in which “if you don't mind my asking" acknowledges the possibility that Van's silence expresses resistance as well as interest.

It seems worth dwelling on some of the other minute effects of Jamesian narration, which, one might say, keeps us alert by never moving at quite the same pace as the action being narrated. In their early manoeuvrings, Van says to Longdon, "I think you ought to give me a little more of a clue."

Mr Longdon took off his glasses. "Well—the clew's [sic] Nanda Brookenham." "Oh, I see." Vanderbank had responded quickly, but for a minute he said nothing more, and the great marble clock that gave the place the air of a club ticked louder in the stillness. (AA 217)

If this were film-that is, sound-film-or theatre-Longdon could take off his glasses as he speaks. And James could have gone for announced if not realised simultaneity: we can imagine another writer giving us: "Taking 
off his glasses, Mr Longdon said, 'Well—the clue's Nanda Brookenham.'” But James's full stop after "glasses" and the hesitating "Well_..." give us a rhythmic sequence- a series of pauses, what film scripts call "beats." We get the gesture. Full stop. Then the speech. Longdon has been buying a tiny bit of time- six words' worth. And varying the rhythm, James has Van respond at once- “Oh, I see”- with then a full stop. Not, doubly not, this: "'Oh, I see,' Van responded quickly..."-but a jump ahead in time after the stop to look back to this in the pluperfect—- $h a d$ responded"-from a further silencewith its own oppressive or at least metronomic imposition of a rhythm: "the great marble clock... ticked louder in the stillness". Another reference to "the stillness," by the way-to maintain the scene's fundamental pianissimo, there throughout as a contrast to the clicks and ticks, the small but intensely significant noises—including speeches.

Prompted by Van's “Oh” here, I'd like to end with one word more, a little word-a word which is almost just a sound. In Either/Or (1843), discussing music, Kierkegaard mocks those (Romantics) by whom "it is assumed that saying 'Uh' is more valuable than a complete thought" (Kierkegaard, qtd. in Halliday 43-44). It certainly needn't be-but in an artistic context it may register more powerfully than many complete thoughts. Let me recall the last spoken lines of John Huston's classic film The Maltese Falcon (1941), where after Brigid O'Shaughnessy, the femme fatale, played by Mary Astor, is led away to trial and execution, the hard-bitten private eye Sam Spade, played by Humphrey Bogart, is left with the cop Polhaus, played by Ward Bond-who picks up and examines the titular, once immensely valuable statuette of a bird which has caused such mayhem.

Policeman: It's heavy. What is it?

Sam Spade: The, er, stuff that dreams are made of.

Spade makes here a dry, glancing Shakespearian allusion-to Prospero's words in The Tempest, IV.1 ("We are such stuff / As dreams are made on"; Shakespeare, 1680). And then the cop replies with what could be the most relishable last word in any film-if it is a "word." "Huh?", he grunts. And nothing more is said. This is powerful not just because it's a dig at the dull 
flatfoot, but because it suggests the depth of the dark vision of human delusion and depravity into which this film of glittering talk has drawn us, from which Detective Tom Polhaus is excluded.

There is then reason to appeal for help here not to Kierkegaard but to Christopher Ricks and his praise of the potential for eloquence of the monosyllabic exclamations "Oh" and "Ah"—though "Uh" and "Huh" are, I know, a little different-in T.S. Eliot and Prejudice (1988):

An exclamation such as Oh or Ah means nothing more (or less) than the tone in which it is uttered; an exclamation is a vacuum waiting to be filled with a tone. Oh and $\mathrm{Ah}$ and Eh are pregnant with potentiality. (Ricks 161)

In other words, we come back to tone. Oh and Ah "throb with actability," we could say - they are sounds as much as words—blank but expressive. "Oh!" occurs 38 times with a simple exclamation mark in The Awkward Age, 92 times unpunctuated in "Oh yes" or "Oh no" or "Oh dear" or whatever, and 282 times after a comma. Still, there is one, taciturn character with whom it is particularly associated: Edward Brookenham. It is said in the novel that "Edward's gloom, on this, was not quite blankness, yet it was dense" (AA 382): he specialises in an inexpressiveness that is hard to read.

When Mr Brookenham appeared his wife was prompt. "She's coming back for Lord Petherton."

"Oh!" he simply said.

"There's something between them."

"Oh!" he merely repeated. But it would have taken many such sounds on his part to represent a spirit of response discernible to any one but his wife. (AA 53)

"Simply," "merely": Edward Brookenham's guarded not-quite-blankness does, James is saying, amount to "a spirit of response"-but only his wife, the monstrous, wonderful Mrs. Brook, a mistress of tone, can read it (and for us these are printed marks, not "sounds").

Even so, the rules of The Awkward Age mean that we have to read his "Ob" - and the hundreds of others in the novel—and work to fill in the blanks. One way of thinking about our place in the distribution of roles in the text is perhaps through the French word interprète-meaning both interpreter and performer. The interpretative act of reading here becomes performativewe act the parts, including of course that of the audience. And as a theatre 
audience changes from night to night, so we are in ourselves, even if only slightly, different from reading to reading - and so the intonations we hear in our sounding of the text will never quite settle, will always have the tantalising elusiveness of a fresh theatrical performance, in which, perhaps, something is always lost on someone, but in which the spectator can be "turned on" with a "click," can "Try to be one of those on whom nothing is lost." 


\section{Works by Henry James}

A-Henry James: Autobiographies. Edited by Philip Horne, Library of America, 2016.

AA-The Awkward Age. Harper \& Brothers, 1899.

CP-The Complete Plays of Henry James. Edited by Leon Edel, Hart-Davis, 1947.

CWD-The Complete Writings of Henry James on Art and Drama: Volume 2: Drama.

Edited by Peter Collister, Cambridge UP, 2016.

FW-Literary Criticism: French Writers, Other European Writers, The Prefaces to the

New York Edition. Edited by Leon Edel \& Mark Wilson, Library of America, 1984.

LL-Henry James: A Life in Letters. Edited by Philip Horne, Penguin Press, 1999.

$N$-The Notebooks of Henry James. Edited by F.O. Matthiessen \& Kenneth Murdock, Oxford UP, 1947.

\section{Other Works Cited}

Coquelin as Rostand's Cyrano de Bergerac, recorded in 1900: https://www.youtube. com/watch?v=-tzmls4gTgQ (consulted 25 January 2020)

Egan, Michael. The Ibsen Years. Vision Press, 1972.

Gooder, Jean. "The Awkward Age: A Study in Ephemera?". The Cambridge Quarterly, vol. 13, no. 1, 1984, pp. 21-39.

Halliday, Sam. Sonic Modernity: Representing Sound in Literature, Culture and the Arts. Edinburgh UP, 2013.

Huston, John. The Maltese Falcon (film). Hollywood: Warner Brothers, 1941. Oxford English Dictionary.

Keating, Peter. The Haunted Study: A Social History of the English Novel 1875-1914. Secker and Warburg, 1989.

Ross, Melanie. "Speech-into-Writing” (conference paper, 4 July 2019, Henry James Society 8th International Conference, Trieste, Italy: The Sound of James: The Aural Dimension in Henry James's Work).

Ricks, Christopher. T.S. Eliot and Prejudice. Faber \& Faber, 1988. 
Shakespeare, William. The Riverside Shakespeare: Second Edition. Edited by Harry Levin, Herschel Baker, Anne Barton, Hallett Smith, Marie Edel, Frank Kermode, G. Blakemore Evans, Houghton, Mifflin, 1997.

Wittgenstein, Ludwig. Tractatus Logico-Philosophicus. Translated by C. K. Ogden, with an Introduction by Bertrand Russell, Routledge \& Kegan Paul, 1922 (repr. 1983). 